\title{
Peran Panwaslu Kota Tangerang Dalam Pengawasan Pemilihan Kepada Daerah Provinsi Banten 2017
}

\section{Dzaki Aziz}

Ilmu Pemerintahan, Fakultas Ilmu Sosial dan Ilmu Politik, Universitas Sultan Ageng Tirtayasa, Jakiajis22@gmail.com

\section{Moh. Rizky Godjali}

Ilmu Pemerintahan, Fakultas Ilmu Sosial dan Ilmu Politik, Universitas Sultan Ageng Tirtayasa, godjalirizki@gmail.com

\begin{abstract}
Abstrak
Panitia Pengawas Pemilu atau biasa disebut Panwaslu merupakan salah satu penyelenggara Pemilu yang memiliki tugas dan kewenangan untuk mengawasi pemilu, pada penyelenggaraan pemilihan Gubernur dan Wakil Gubernur di Banten 2017. Panwaslu Kota Tangerang sebagai salah satu penyelenggara pemilu memiliki tugas dan wewenang untuk mengawasi jalannya pemilihan diwilayah Kota Tangerang. Tujuan Penelitian ini adalah untuk mendeskripsikan peran Panwaslu Kota Tangerang dalam Pengawasan Pemilihan Gubernur dan Wakil Gubernur Banten 2017. Pendekatan yang digunakan dalam penelitian ini adalah penelitian kualitatif deskriptif dengan menggunakan teknik pengumpulan data berupa wawancara dan juga studi dokumen. Berdasarkan hasil penelitian maka dapat disimpulkan bahwa Panwaslu Kota Tangerang dalam pengawasan pemilihan Gubernur dan Wakil Gubernur Banten 2017 telah melakukan tugasnya sesuai dengan peraturan perundang-undangan, namun dalam pelaksanaan tugasnya mengalami memiliki hambatan. Panwaslu mengawasi KPU, peserta pemilu dan pemilih dengan cara mengikuti setiap tahapan pemilihan yang ada dan juga Panwaslu memiliki lembar laporan yang akan menjadi acuan dalam melakukan segala tindakan atau memberikan rekomendasi kepada KPU. selain itu juga panwaslu mengawasi pemilih, dalam mengawasi pemilih itu sendiri seperti mengawasi daripada netralitas Aparatur Sipil Negara (ASN) Panwaslu juga mengingatkan serta memberikan peringatan terhadap ASN terlebih dengan memberikan sosialisasi tentang pentingnya netralitas ASN dalam pemilu, namun yang terjadi masih saja ditemukan pelanggaran yang dilakukan dan Panwaslu hanya dapat memberikan surat peringatan atau melakukan pemanggilan namun tidak dilakukan sanksi apapun terhadap pelanggar tersebut.
\end{abstract}

Kata kunci: pemilu , pengawasan, panwaslu, peran 
Abstract:

The Election Oversight Committee or commonly called Panwaslu is one of the organizers of the Election who has the duty and authority to oversee the election, in organizing the election of Governor and Deputy Governor in Banten 2017. The Tangerang City Election Supervisory Committee as one of the election organizers has the duty and authority to oversee the election in the City Tangerang. The purpose of this research was to describe the role of Tangerang City Panwaslu in Supervising the Election of Banten Governor and Deputy Governor of 2017. The approach used in this study was descriptive qualitative research using data collection techniques in the form of interviews and document studies. Based on the results of the study, it can be concluded that the Panwaslu of the City of Tangerang in the supervision of the election of the Governor of Banten and Deputy Governor of 2017 has carried out their duties in accordance with the laws and regulations, but in carrying out their duties they have obstacles. The Election Supervisory Committee oversees the KPU, election participants and voters by following each election stage and Panwaslu has a report sheet that will become a reference in taking all actions or providing recommendations to the KPU. besides that the Election Supervisory Committee oversees the voters, in overseeing the voters themselves such as overseeing the neutrality of the State Civil Apparatus (ASN) Panwaslu also reminded and warned against ASN especially by providing socialization on the importance of ASN neutrality in elections, but violations were committed. Panwaslu can only give warning letters or make summons but no sanctions are imposed on the violator.

Keywords : elections, supervision, panwaslu, role

\section{Pendahuluan}

Indonesia merupakan negara penganut paham demokrasi yang berarti kedaulatan berada di tangan rakyat. Pemilihan umum dipandang sebagai bentuk paling nyata dari kedaulatan yang berada di tangan rakyat dalam penyelenggaraan Negara. Menurut UU No.8 tahun 2012 tentang Pemilihan Umum Anggota Dewan Perwakilan Rakyat, Dewan Perwakilan Daerah, dan Dewan Perwakilan Rakyat Daerah. Dalam pasal 1 angka 1 disebutkan pemilihan umum, selanjutnya disebut pemilu, adalah sarana pelaksanaan kedaulatan rakyat yang dilaksanakan secara langsung, umum, bebas, rahasia, jujur dan adil dalam Negara Kesatuan Republik Indonesia berdasarkan Pancasila dan Undang -Undang Dasar Negara Republik Indonesia Tahun 1945.

Berdasarkan Undang-Undang Nomor 1 Tahun 2015 tentang pemilihan gubernur dan wakil gubernur, bupati dan wakil bupati serta walikota dan wakil walikota, pemilihan umum (pemilu) adalah proses memilih orang untuk mengisi jabatan- jabatan politik tertentu. Pemilu dilaksanakan dengan menganut asas langsung, umum, bebas, rahasia, jujur, dan adil. Untuk menjalankan pemilu, maka terdapat penyelenggara pemilu. Penyelenggara tersebut yaitu Komisi Pemilihan Umum (KPU),

Badan Pengawas Pemilihan Umum. 
Pada tahun 2017 dilaksanakan Pilkada di 7 provinsi di Indonesia dan Provinsi Banten termasuk dalam provinsi yang menyelenggarakan pilkada serentak yaitu dalam pemilihan gubernur dan wakil gubernur Banten tahun 2017 . secara keseluruhan terdapat 101 daerah yang menyelenggarakan pilkada serentak yang terdiri dari 7 provinsi, 76 kabupaten, dan 18 kota. Pada penyelenggaraan Pilgub Banten 2017 ini terdapat dua pasangan calon Gubernur dan wakil Gubernur yaitu Rano-Embay dan Wahidin-Andika dan hasil akhir menunjukan bahwa WahidinAndika unggul 89,890 Surat Suara dibandingakan dengan Rano-Embay (KPU Provinsi Banten)

Dalam pelaksanaan pemilu terdapat beberapa tahapan pemilu, menurut Peraturan Komisi Pemilihan Umum (PKPU) Nomor 3 Tahun 2016 Tentang Tahapan, Program dan Jadwal Penyelenggaraan Pemilihan Gubernur dan Wakil Gubernur, Bupati dan Wakil Bupati dan/atau Walikota dan wakil Walikota Tahun 2017 telah diterbitkan oleh KPU RI. Tahapan Pemilu terbagi menjadi dua yaitu persiapan dan penyelenggaraan. Tahapan persiapan terdiri dari; tahap perencanaan program dan anggaran, penyusunan peraturan penyelenggaraan pemilihan, sosialisasi, penyuluhan dan bimbingan teknis, pendaftaran pemantau pemilihan, pengolahan Daftar Penduduk Potensi Pemilih Pemilihan (DP4), serta pemutakhiran data. Tahapan penyelenggaraan pemilu yaitu ; Penyusunan daftar pemilih sementara (DPS), Daftar Pemilih Tetap (DPT), Sebelum Masa Kampanye, MasaKampanye, Masa tenang, pengadaan dan distribusi perlengkapan pemungutan suara, pemungutan suara dan penghitungan,Rekapitulasi hasil penghitungan suara, penetapan dan pengumuman pasangan calon terpilih, permohonan perselisihan hasil pemilihan, sengketa hasil perselisihan hasil pemilihan, penetapan dan pengumuman pasangan calon terpilih paska putusan Mahkamah Konstitusi (MK).

Semua tahapan yang ada dalam Peraturan Komisi Pemilihan Umum (PKPU) Nomor 3 Tahun 2016 Tentang Tahapan penyelenggaraan diawasi oleh panitia pengawas pemilu atau Panwaslu. Panwas (Panitia Pengawas) adalah sebutan lembaga/kepanitiaan yang dibentuk khusus dalam rangka mengawasi penyelenggaraan pesta demokrasi Indonesia. Panwaslu sebelumnya merupakan bagian dari struktur KPU namun setelah tahun 2003 Melaui UU No. 12/2003 menegaskan Panwaslu sudah tidak di dalam struktur KPU dan untuk melakukan pengawasan Pemilu, dibentuk Panitia Pengawas Pemilu, Panitia Pengawas Pemilu Provinsi, Panitia Pengawas Pemilu Kabupaten/Kota, dan Panitia Pengawas Pemilu Kecamatan.

Pemilihan umum di Indonesia sebagai salah satu upaya mewujudkan negara demokrasi haruslah dapat dilaksanakan dengan baik agar terciptanya pemilihan umum yang profesional dan memiliki kredibilitas yang dapat dipertanggung jawabkan. Pemilu merupakan bagian yang sangat penting dalam kehidupan sistem politik, begitu pula dengan pengawasan terhadap pemilu itu sendiri dikarenakan untuk mewujudkan pemilu yang jujur dan adil dibutuhkan sebuah pengawasan 
agar jalannya penyelenggaraan pemilu dapat berjalan dengan baik (Hikmawan, 2017b).

Besarnya tantangan demokrasi dalam bentuk pemilihan umum (pemilu) pada masa yang akan datang membuat kita harus berpikir lebih jauh lagi untuk dapat menjaga kualitas dari perhelatan demokrasi itu sendiri. Dikutip dalam laman Panwaslu.setkab.go.id dikatakan indikator sukses atau tidak sebuah pemilu ditentukan oleh tiga (3) hal penting. Proses penyelenggaraannya, aturan hukum, dan penegakan hukum. Pada proses penyelenggaraannya adalah pesertanya, tahapannya, logistik, dan distribusi, serta pemantau dan partisipasi masyarakat. Keberhasilan pemilihan umum bukan hanya saja tergantung terhadap KPU sebagai penyelenggara, namun juga peranan Panitia Pengawas pemilu atau yang biasa disebut Panwaslu juga sangat penting demi terwujudnya pemilihan umum yang Jujur dan adil juga serta pentingnya peran serta yang aktif dari publik untuk bersama-sama melakukan pengawasan (Widiyanto, Hikmawan, \& Riswanda, 2019).

\section{Kerangka Teori}

Berkaca pada pemilihan umum sebelum-sebelumnya, bentuk dan macam pelanggaran masih sering terjadi meskipun panitia pengawas dan jajarannya telah berupaya semaksimal mungkin melakukan pengawasan melalui strategi-strategi pencegahan pelanggaran pemilu. Pelaksanaan Pemilu sendiri tidaklah lepas dari berbagai permasalahan yang timbul karena suatu perbuatan baik yang dilakukan oleh Warga Negara Indonesia (WNI) dan peserta Pemilu itu sendiri (Roni Wiyanto hal.26).

Di Provinsi Banten pada pelaksanaan pilgub banten 2017 , Bawaslu Provinsi Banten menerima 79 laporan dugaan pelanggaran kampanye yang diduga dilakukan pasangan calon Gubernur dan calon wakil Gubernur Banten, Wahidin Halim-Andika Hazrumy dan duet Rano Karno-Embay Mulya Syarief. Untuk Kota Tangerang sebanyak 18 laporan pelanggaran pemilu yang dilaporkan oleh kubu duet Rano dan Embay Mulya syarief Selanjutnya Dari beberapa laporan di atas hanya dua yang di tindak lanjuti yaitu laporan temuan perihal dugaan pembukaan kotak suara di kecamatan Tangerang dan kecamatan Karawaci pada TPS 7 dan 3 kelurahan kelapa indah dan Sukarasa serta TPS 5 dan 15 di kelurahan Sukajaya. Panwaslu kota Tangerang memberikan rekomendasi kepada KPU kota Tangerang untuk melakukan Pemungutan suara ulang (PSU) sesuai dengan ketentuan peraturan Undang-Undang Nomor 1 Tahun 2015 tentang Pemilihan Kepala Daerah ayat 2 huruf a dan Peraturan KPU Nomor 14 Tahun 2016 ayat 1. (Panwaslu Kota Tangerang)

Selain itu banyak sekali dilapangan permasalahan yang terjadi pada penyelenggaraan pemilu secara garis besar permasalahan yang sering muncul pada saat pelaksanaan pemilu antara lain, pertama daftar pemilih tidak akurat antara data 
daftar penduduk potensial pemilih pemilu (DP4) dari Dinas kependudukan dan pencatatan sipil kota Tangerang dengan data applikasi Sistem data Pemilih (Sidalih) yang dimiliki KPU pada Pilgub Banten yaitu terdapatnya perbedaan jumlah Daftar Pemilih Tetap (DPT), pada DP4 tercatat sebanyak 1.379.198 pemilih sedangkan data sidalih sebanyak 1.127.914. Seharusnya Panwaslu melakukan penyelarasan data dengan memberikan laporan pengawasan serta laporan pengaduan masyarakat yang namanya tidak tercantum di dalam DPT, sesuai dengan kewajibannya Panwaslu yang tercantum dalam Undang-undang No. 7 Tahun 2017 pasal 104 yaitu mengawasi pemutakhiran dan pemeliharaan data pemilih secara berkelanjutan yang dilakukan oleh KPU (kabupaten/Kota dengan memperhatikan data kependudukan. Untuk memastikan bahwa seluruh masyarakat dapat terpenuhi hak untuk dapat memilih pada pemilihan Gubernur di wilayah Kota Tangerang.

Kedua pengawasan Panwaslu yang kurang maksimal dalam setiap tahapan penyelenggaraan pemilu dimana seharusnya Panwaslu mengawasi setiap tahapan yang dilaksanakan oleh penyelenggara pemilihan sesuai dengan tugas Panwaslu yang tercantum dalam Undang-undang No. 7 Tahun 2017 Pasal 101 ayat b yaitu mengawasi setiap pelaksanaan tahapan Penyelenggaraan Pemilu di wilayah kabupaten/kota. Ketiga minimnya sumber daya manusia dan anggaran membuat sosialisasi yang dilakukan kepada masyarakat tentang pentingnya partisipasi masyarakat dalam pengawasan masih minim, dan juga masih masih kurangnya sosialisasi tentang tatacara pelaporan pelanggaran pemilu kepada masyarakat luas. dimana seharusnya Panwaslu sesuai dengan tugas dan fungsinya memberikan sosialisai kepada masyarakat sesuai dengan tugas Panwaslu Kota yang tercantum dalam Undang-undang No. 7 Tahun 2017 Pasal 102 ayat b yaitu meningkatkan partisipasi masyarakat dalam pengawasan Pemilu di wilayah kabupaten/kota.

Keempat Sifat Ad hoc pada Panwaslu dari tingkat Kecamatan hingga kelurahan menyebabkan terhambatnya pelaksanaan tugas pengawasan yang dilakukan oleh Panwaslu serta mengakibatkan penggunaan anggaran yang tidak efektif sehingga menyebabkan sulitnya untuk melakukan pembinaan yang berkelanjutan kepada jajaran dibawahnya mulai dari pendidikan pemilih dan pengawasan partisipatif.

Kelima yaitu masih belum tegasnya Panwaslu terhadap penyelesaian dugaan Aparatur Sipil Negara (ASN) yang tidak netral, hal ini bisa terlihat dari tidak jelas dan tidak tuntasnya dugaan pelanggaran ASN yang berpihak kepada salah satu calon yaitu dengan mengadakan bakti sosial dengan menyertakan bendera salah satu parpol bakal calon di Pilgub Banten 2017. Dimana seharusnya Panwaslu sesuai dengan Undang- undang No. 7 Tahun 2017 sesuai dengan salah satu tugas dan fungsinya yaitu mengawasi netralitas ASN agar terciptanya pemilihan yang demokratis.

Berdasarkan latar belakang masalah yang penulis kemukakan diatas, maka perumusan masalah dalam penelitian ini adalah "Bagaimana Peran Panwaslu Kota Tangerang dalam Pengawasan Pemilihan Gubernur Banten dan Wakil Gubernu Banten Pada Tahun 2017?" 


\section{Metode Penelitian}

Jenis penelitian yang dianggap tepat untuk digunakan dalam tulisan ini adalah metode penelitian kualitatif. Menurut Creswell (2014:59) penelitian kualitatif dimulai dengan asumsi dan penggunaan kerangka penafsiran/teoritis yang membentuk atau memengaruhi studi tentang permasalahan riset yang terkait dengan makna yang dikenakan oleh individu atau kelompok pada suatu permasalahan sosial atau manusia.

Metode ini digunakan peneliti dalam mendeskripsikan tujuan dari penelitian yaitu mengenai Peran Pengawasan Panwaslu Kota Tangerang dalam Pilgub Banten tahun 2017. Dalam penelitian ini, peneliti menggunakan metode penelitian dengan pendekatan studi kasus. Menurut Yin dalam Creswell (2014:135) pendekatan studi kasus mencakup studi tentang suatu kasus dalam kehidupan nyata, dalam konteks atau setting kontemporer (Hikmawan, 2014).

\section{Hasil dan Diskusi}

\section{Kesiapan Panwaslu Kota Tangerang dalam Menghadapi Pilgub Banten 2017}

Untuk kesiapan Sumber Daya Manusia Panwaslu khususnya Kota Tangerang dalam menghadapi Pemilihan Gubernur Banten, pada Tanggal 11 Juli 2016 sampai dengan Tanggal 17 Juli 2016 Panitia Pengawas Pemilihan Umum (Panwaslu) membuka kesempatan atau Pendaftaran Panitia Pengawas Kecamatan (Panwascam) se-Kota Tangerang. Kesempatan tersebut disambut antusias oleh para Calon Pendaftar yang mempunyai integritas, sehingga Sekretariat Panwaslu di Jalan Kisamaun No. 24 Kelurahan Sukasari, Kecamatan Tangerang, Kota Tangerang didatangi oleh para warga untuk Pengambilan Formulir Pendaftaran sebagai Panwascam. Ketua Panwaslu Kota mengatakan bahwa:

"Partisipasi masyarakat tinggi untuk pemilihan Gubernur dan Wakil Gubernur Banten. Formulir Pendaftar sebanyak 88 berkas dari 98 lembar formulir telah diambil calon pendaftar. Masyarakat sudah banyak yang mengambil Formulir Pendaftaran Panwascam."(Agus Muslim - Ketua Panwaslu Kota Tangerang)

Dalam mempersiapkan Sumber Daya Manusia (SDM) Panwaslu Kota Tangerang dalam menghadapi Pemilihan Gubernur Banten, Panwaslu memberikan kesempatan untuk berpartisipasi bagi masyarakat untuk menjadi Panwascam agar pemantauan ke tingkat Kecamatan lebih kondusif dan efektif.

Panitia Pengawas Pemilu (Panwaslu) Kota Tangerang menggelar bimbingan teknis (bintek) kepada seluruh anggota panwascam. Bintek dilakukan dalam rangka penguatan kapasitas sumber daya manusia (SDM) dan tenaga kesekretariatan di lingkup panwaslu. Kegiatan tersebut dihadiri 39 anggota Panwascam dari seluruh kecamatan yang ada di Kota Tangerang. Ketua Panwaslu Kota Tangerang mengatakan: 
Volume 1 Issue 1, April 2019

http://hk-publishing.id/ijd-demos

"Kegiatan tersebut terkait pembuatan laporan pertanggung jawaban keuangan. Sekaligus penguatan secara teknis". (M Agus Muslim- Ketua Panwaslu Kota Tangerang).

Menurut Ketua Panwaslu Kota Tangerang, hal tersebut juga harus diprioritaskan, karena kegiatan pelaporan harus konsisten dan tidak bisa ditundatunda. Secara teknis dalam pembuatan laporan tersebut SDM harus betul-betul menguasainya.

"Baik itu penguasaan teknik pelaporan. Dalam kegiatan ini juga ikut dilibatkan kepala kesekretariatan, bendahara, dan semua komisioner". (Agus Muslim - Ketua Panwaslu Kota Tangerang)

Untuk Komisi Pemilihan Umum (KPU) Kota Tangerang telah memastikan melibatkan lebih kurang sebanyak 22.629 Penyelenggara Pemilihan Gubernur dan Wakil Gubernur Banten Tahun 2017. Puluhan ribu Penyelenggara ini merupakan Sumber Daya Manusia (SDM) yang telah ditetapkan mulai dari tingkatan KPU, PPK, PPS, KPPS hingga Petugas Ketertiban TPS. Dalam mempersiapkan Sumber Daya Manusia (SDM), Ketua KPU Kota Tangerang mengatakan:

"Secara SDM kami sudah siap. Apalagi, terhitung sejak 14 Februari, sebanyak 22.121 penyelenggara di tingkat TPS sudah terbentuk. Mereka terdiri dari 17.276 Kelompok Penyelenggara Pemungutan Suara (KPPS) dan 4.936 Petugas Ketertiban TPS". (Sanusi Pane-Ketua KPU Kota Tangerang)

Dalam rangka persiapan rekrutmen Panitia Pengawas Pemilihan Kecamatan (Panwascam) pada Pilgub Banten, Bawaslu Banten menekankan agar rekrutmen Panwascam harus mengutamakan Sumber Daya Manusia (SDM) yang memiliki integritas, jujur dan adil. Hal tersebut disampaikan dalam Rakernis Penyelenggaraan Pengawasan Pilgub Banten Tahun 2017 yang diikuti oleh Panwaslu Kab/Kota se Provinsi Banten di Le Dian Serang 23-25 Juni 2016. Divisi Organisasi dan SDM Bawaslu Provinsi Banten menyempaikan bahwa Panwascam berfungsi sebagai kepanjangan tangan Panwaslu Kab/Kota yang memudahkan pengawasan berdasarkan geografis kecamatan.

"Dalam Perekrutan Panwascam, Panwaslu Kab/Kota harus memilih SDM Pengawas di tingkat kecamatan yang memiliki integritas tinggi, berjiwa kuat, jujur dan adil. Selain itu, Panwascam dimaksudkan untuk memudahkan dalam pengawasan di lapangan dan mampu membuat laporan pengawasan." (Nuryati Sola Pari Komisioner Bawaslu Provinsi Banten)

Pada pelaksanaannya, terdapat beberapa kendala dalam hal SDM pada tingkat kecamatan dimana pada tingkat kecamatan terdapat tiga orang anggota Panitia pengawas kecamatan dan juga kesekretariatan yang terdiri dari satu orang Kepala Sekretariat dan juga beberapa Staff dalam hal ini tidak di atur bagaimana tugas pokok dan fungsi masing-masing didalam kesekretariatan hal ini berdampak kepada anggota Panwaslu yang terdiri dari tiga orang Komisioner terhambat 
kinerjanya yang pada akhirnya juga berdampak terhadap Panwaslu tingkat Kota dikarenakan pada tingkatan kecamatan pengorganisasian tugas pokok dan fungsi sekretariatan belum terkelola dengan baik.

Untuk mencapai penyelenggaraan yang baik Panwaslu mengacu pada tugas pokok dan fungsinya agar tercapai pengawasan yang baik sudah seharusnya mempersiapkan SDM beserta pengelolaan organisasi yang baik agar tidak menghambat kinerja pada pelaksanaan pengawasan mulai dari pengorganisasian tingkat Kota hingga tingkat bawah lebih mendetail seperti sekretariatan dan tugas pokok dan fungsinya.

Dari paparan diatas dapat ditarik kesimpulan bahwa kesiapan Sumber Daya Manusia (SDM) Panwaslu Kota Tangerang belum cukup matang memengingat belum tertata dengan baik kesekretariatan pada tingkat kecamatan yang pada akhirnya berdampak kepada tugas pengawasan Panwaslu Kota dalam menjalankan peran pengawasannya di Pemilihan Gubernur dan Wakil Gubernur .

\section{Daya Dukung Panwaslu}

Dalam menangani dan penertiban dan Daya Dukung Panwaslu Kota Tangerang melalui Komisi Pemilihan Umum (KPU) Banten menetapkan batasan pembuatan alat peraga kampanye (APK) dan juga titik pemasangannya bagi Pasangan Calon Gubernur dan Wakil Gubernur Banten 2017. Dengan penetapan jumlah cetak APK tersebut, maka hanya ada 1.891 titik pemasangan APK yang boleh beredar di Kota Tangerang

Dalam hal dukungan ini termasuk dari jajaran Kepolisian Resort (Polres) Metro Tangerang Kota, Komisi Pemilihan Umum (KPU) Kota Tangerang dan Pengawas Pemilihan Umum (KPU) Kota Tangerang komitmen menjadikan Pemilihan Gubernur dan Wakil Gubernur Banten 2017 bersih dan obyektif. Demikian terungkap saat pemaparan Pilkada Bersih dan Obyektif kepada seluruh jajaran Bhabikamtibmas (Bhayangkara Pembina Keamanan dan Ketertiban Masyarakat) se-Kota Tangerang, di Aula Polres Metro Tangerang Kota, oleh Kapolres Metro Tangerang, Kombespol Irman Sugema, Ketua KPU Kota Tangerang, Sanusi, dan Ketua Panwaslu Kota Tangerang Agus Muslim, (Jumat 30 September 2016).

Dari pemaparan di atas dapat diketahui untuk tercapainya penyelenggaraan Pemilu yang baik Panwaslu juga bersinergi dengan beberapa lembaga seperti Kepolisian, Satuan Polisi Pamong Praja terlebih dalam pelaksanaan peran pengawasan pada setiap tahapan pemilu, seperti pada tahapan masa tenang, tahapan kampanye. Panwaslu bersinergi dengan Satpol PP untuk melakukan pembersihan APK dan bersama-sama melakukan pembersihan Alat Peraga Kampanye (APK) jika terindikasi terjadi pelanggaran pemasangan atau tidak sesuai dengan titik yang diperbolehkan untuk melakukan pemasangan APK

\section{Sosialisasi Penyelenggaraan Pemilu}

Komisi Pemilihan Umum (KPU) Kota Tangerang bersama Persatuan Wartawan Indonesia (PWI) Kota Tangerang menggelar Deklarasi Jurnalis Kawal Demokrasi untuk Pemilihan Kepala Daerah (Pilkada) Banten yang berkualitas. Deklarasi digelar di Wisma PGRI, Jalan A Damyati, Kelurahan Sukarasa, Kecamatan Tangerang, Kota Tangerang, Pada Kamis Tanggal 15 Desember 2016. Ketua KPU Kota Tangerang mengatakan: 
Volume 1 Issue 1, April 2019

http://hk-publishing.id/ijd-demos

"Para insan pers dalam berperan pada Pilkada Banten mempunyai tingkat yang cukup tinggi untuk meningkatkan partisipasi pemilih. Maka peran kawan-kawan pers sangat dibutuhkan". (Sanusi Pane-Ketua KPU Kota Tangerang)

Panwaslu Kota Tangerang beserta KPU Kota Tangerang berharap, Pilkada Banten ini dapat dibantu media massa dalam mensosialisasikan kepada masyarakat agar partisipasi pemilih dapat meningkat dari Pilpres kemarin. Selain itu, Ketua Panwaslu Kota Tangerang menekankan terhadap pemerintah daerah dalam pelaksanaan Undang-Undang (UU) Pemiihan Umum (Pemilu) pada pasal 113 A. Diketahui, pada pasal itu, pemerintah wajib dalam mensosialisasikan Pilkada dalam meningkatkan partisipasi pemilih.

Sosialisasi juga diharapkan dapat menimbulkan peran aktiv dari warga masyarakat dalam mengawasi kegiatan pemilu Kegiatan pemantauan atas setiap tahapan Pemilu, seperti menyampaikan pengaduan tentang dugaan pelanggaran Pemilu, hitungan Cepat, dan kegiatan merekam dan menyebar-luaskan hasil Pemilu merupakan sebagian kegiatan yang berkaitan dengan pengawasan partisipatif dalam pemilu, yang tujuannya untuk memastikan suara setiap pemilih menjadi bagian dari keputusan KPU tentang hasil pemilu. Kegiatan pengawasan partisipatif ini adalah upaya untuk memastikan setiap pemilih memberikan suara secara cerdas, yang dapat dilakukan oleh pemilih (sendiri atau berkelompok), LSM, lembaga pemantau Pemilu, peserta Pemilu, lembaga survey, mereka yang berkarya di media massa, akademisi, kelompok profesi, dan organisasi kemasyarakatan (Surbakti, 2015: 51).

Pada pelaksanaan sosialisasi dilapangan diketahui bahwa pada setiap sosialisasi yang dilakukan oleh KPU maupun Panwaslu selalu saja melibatkan atau mengundang tokoh-tokoh masyarakat, Organiasi Masyarakat, Rt/Rw dan setiap sosialisasi selalu mengundang yang sudah mendapatkan sosialisasi sebelumnya ini juga menyebabkan hanya beberapa orang saja yang memahami sosialisasi yang dilakukan tersebut. Karena seharusnya sesuai dengan tugas pokok dan fungsi dari Panwaslu pada UU No.7 Tahun 2017 Pasal 104 Panwaslu kota berkewajiban untuk mengembangkan pengawasan pemilu partisipatif yang bertujuan untuk menciptakan pemilu yang demokratis (Hikmawan \& Hidayat, 2016). Pelibatan dan Partisipasi masyarakat menunjukkan satu kewajiban bawaslu sebagai fungsi yang terlembaga dalam pengawasan pemilu, sedangkan partisipasi masyarakat lebih pada penggunaan hak warga negara untuk mengawal hak pilihnya. namun, pelembagaan pengawasan itu tidak serta-merta mengambil hak masyarakat untuk ikut melakukan fungsi kontrolnya dalam menjaga suara atau kedaulatan rakyat.

\section{Sumber Daya Keuangan Panwaslu}

Ketua Badan Pengawas Pemilihan Umum (Bawaslu) Provinsi Banten Pramono U Tantowi mengungkapkan dalam bantuan keuangan dari Pemerintah Provinsi (Pemprov) Banten untuk penyelenggaran Pemilihan Gubernur (Pilgub) 2017 sebesar Rp 50 miliar, Ketua Bawaslu Provinsi Banten juga menjelaskan bahwa di Banten sendiri ada 1.551 Desa/ Kelurahan yang jadi wilayah kerja PPL. Belum lagi pengawas TPS.

"Jumlah TPS sebanyak 16.500 se-Banten. Total honor dan operasional petugas TPS itu 
Volume 1 Issue 1, April 2019

http://hk-publishing.id/ijd-demos

Rp 1 juta. Kalau dikalikan jumlah TPS, maka kebutuhannya mencapai Rp 16,5 miliar". (Pranomo U Tantawi, Jum'at 29 April 2016).

Selanjutnya mengenai Anggaran Pemilihan Gubernur Tahun 2017, KPU Banten mengeluh terkait Anggaran untuk penyelenggaran Pilgub Banten 2017 yang telah dialokasikan dalam APBD Banten Tahun 2016 senilai Rp 150 miliar, sementara dengan jumlah sebesar itu dinilai masih kurang. Karena itu, KPU Banten berharap pada APBD perubahan Pemprov Banten bisa menganggarkan lagi sehingga bisa mencapai Rp 300 miliar.

"Naskah Perjanjian Hibah Daerah (NPHD) untuk Pilgub Banten telah kami tandatangani bersama Pemprov Banten dan Badan Pengawas Pemilihan Umum (Bawaslu) Banten. Anggaran Pilgub yang dianggarkan dari dana hibah, yang tercantum dalam NPHD itu sebesar Rp 150 miliar. Anggaran tersebut masih kurang". (Syaiful Bahri, Komisioner KPU Banten, Rabu, 26 April 2016).

Anggaran Rp 150 miliar tersebut diprediksi oleh Komisioner KPU Provinsi Banten hanya cukup hingga Oktober 2016. Anggaran tersebut digunakan untuk honor para penyelenggara, PPK, PPS, Sosialisasi, Launching Pilkada, dan Pengadaan Alat Sosialisasi. Sementara KPU Banten mengajukan Anggaran Pemilihan Gubernur dan Wakil Gubernur Banten Tahun 2017 sebesar Rp. 299 miliar.

Ketua KPU Banten menjelaskan ada beberapa komponen masyarakat dari Tangerang dan Serang yang menanyakan proses pencalonan Gubernur Banten untuk calon perseorangan. Jika mengacu pada Undang-undang No 8 Tahun 2015, untuk daerah dengan jumlah penduduk 10 sampai 12 juta orang, maka dukungan untuk calon perseorangan sekitar 7,5 persen dukungan dalam bentuk KTP.Sedangkan calon gubernur yang diusung Partai Politik, Ketua KPU Banten mengatakan, menurut Undang-undang No 8 Tahun 2015 harus mendapatkan minimal 20 persen dari jumlah kursi yang ada di DPRD.

Dari beberapa Penuturan diatas dapat diperoleh informasi bahwa anggaran penyelenggaraan Pilgub Banten 2017 masih minim untuk dapat memenuhi kebutuhan penyelenggaraan itu sendiri baik Panwaslu Kota Tangerang dan juga KPU hal ini menyebabkan tidak optimalnya tugas dari Panwaslu sendiri yang dimana anggaran tersebut hanya dapat menutupi pembayaran honor pada tingkat bawahnya

\section{Regulasi Panwaslu Kota Tangerang}

Dalam pemilihan umum Pilgub dan Wagub Panwaslu sangatlah berperan aktif dalam menangani masalah-masalah dalam penyelenggaraan Pilgub dan Wagub. Peranan dan fungsi Panwaslu tertuang dalam Undang-Undang Nomor 22 tahun 2007 yang menyebutkan bahwa fungsi Pengawas Pemilu yang dijabarkan dalam tugas, wewenang dan kewajiban Pengawas Pemilu. Berkaitan pelaksanaan tugas sebagai pengawasan pemilu ada pembagian-bagian tugas atara lain sebagai berikut:

a.Bawaslu melakukan pengawasan terhadap seluruh tahapan penyelenggaraan Pemilu; Panwaslu Provinsi mengawasi tahapan penyelenggaraan Pemilu di wilayah provinsi;Panwaslu kabupaten/kota mengawasi penyelenggaraan Pemilu 
di wilayah kabupaten/kota;Panwaslu Kecamatan mengawasi tahapan penyelenggaraan Pemilu di wilayah kecamatan;Pengawas Pemilu Lapangan mengawasi tahapan penyelenggaraan Pemilu ditingkat desa/kelurahan; dan Pengawas Pemilu Luar Negeri mengawssi tahapan penyelenggaraan Pemilu di luar negeri.

Dari hasil wawancara dengan dengan Ketua KPU Kota Tangerang Sanusi Pane, Peneliti memperoleh informasi bahwa pada saat pemilihan umum tahun 2017 jumlah DPT yang ditetapkan sebanyak 1.127.914 yang terdiri dari 2.468 TPS. Selanjutnya penyelenggaraan pilgub Banten di kota Tangerang sendiri memiliki beberapa laporan pelanggaran sesuai dengan yang dikatakan oleh ketua Panwaslu Kota Tangerang :

"Pelanggaran yang muncul pada pilgub kemarin banyak sekali laporan tentang suket palsu, lalu surat suara palsu, penggelembungan surat suara, pembukaan kotak suara tidak sesuai dengan prosedur, dan ASN yang tidak netral. (Ketua Panwaslu Kota Tangerang Tahun 2017 - M Agus Muslim)"

Dalam setiap tahapan penyelenggaraan Pilgub Banten Panwaslu melakukan pengawasan terhadap penyelenggaraan pemilu, mengawasi dan mengikuti setiap tahapan-tahapan kegiatan yang dilakukan oleh KPU, agar pelaksanaan pemilu sesuai dengan harapan:

"Kami melakukan dengan mengikuti setiap kegiatan atau tahapan yang dilakukan KPU, karena sesuai dengan tugas kami yaitu mengawasi dan juga melaporkan hasil pengawasan kepada Bawaslu Provinsi. Seperti melakukan sosialisasi pun kami ikut didalamnya atau yang biasa kita sebut dengan waskat yaitu pengawasan melekat" (Komisioner Panwaslu Kota Tangerang Tahun 2017 - Herry Handani).

Disini dapat kita ketahui Pengawasan yang dilakukan oleh Panwaslu dilakukan dengan pengawasan yang melekat kepada KPU sebagai salah satu penyelenggara proses pemilu, semua tahapan di awasi oleh panwaslu hal ini disampaikan oleh ketua KPU Kota Tangerang :

"Selama penyelenggaraan pilgub kemarin panwaslu mengawal kami dengan baik, segala rekomendasi kami laksanakan . saat kami melakukan kegiatan pasti melaporkan kepada panwaslu dan mengundangnya." (Sanusi Pane - Ketua KPU Kota Tangerang)

Dari penuturan diatas dapat kita peroleh informasi Pengawasan pelaksanaan Pilgub Banten 2017 oleh Panwaslu Kota Tangerang mendapatkan beberapa laporan pelanggaran serta pengawasan yang dilakukan oleh Panwaslu dilakukan dengan pengawasan yang melekat pada setiap tahapan yang dilakukan oleh KPU Kota Tangerang .

\section{Pengawasan Pemilih}

Panwaslu melakukan pengawasan terhadap peserta pemilu dalam hal ini yaitu Calon Gubernur dan Wakil Gubernur Banten Rano-Embay dan juga Wahidin dan Andika. Menurut UU No. 7 Tahun 2017 Panwaslu sudah seharusnya berkewajiban 
untuk bersikap adil dalam melaksanakan tugas dan wewenangnya. Panwaslu melakukan pengawasan terhadap calon mulai dari tahap administrasi pencalonan, tahap kampanye hingga proses sengketa.

Pengawasan terhadap peserta pemilu meliputi pengawasan mulai dari administrasi agar segala bentuk dokumen sesuai dengan ketentuan yang ditetapkan dalam pemilihan, pengawasan peserta pada tahapan kampanye dan pemungutan suara . seperti pada tahapan Kampanye Panwaslu memiliki melakukan pengawasan dengan melakukan pemantauan langsung dilapangan dengan melaporkan segala bentuk kejadian yang terjadi dilapangan hal tersebut ditulis didalam Formulir A , Form tersebut berisi tentang bagaimana acara tersebut berjalan, berapa banyak masa yang datang, konsumsi apa yang disediakan, Alat peraga kampanye apa yang digunakan, terdapat hiburan pada acara tersebut atau tidak, apakah ditemukan pelanggaran pada saat acara tersebut berjalan. Form tersebut yang menjadi acuan jika terjadi indikasi pelanggaran

\section{Pengawasan Penyelenggara Pemilu}

Selain melakukan pengawasan terhadap peserta pemilu, Panwaslu Kota Tangerang juga melakukan pengawasan terhadap Penyelenggara pemilu yaitu KPUD Kota Tangerang . sesuai dengan UU No. 7 tahun 2017 bahwa tugas dan wewenang Panwaslu yaitu untuk mengawasi setiap tahapan Pemilu. Panwaslu melakukan pengawasan terhadap KPUD sendiri salah satunya pada tahapan penetapan DPT, yaitu dengan cara membandingkan data yang dimiliki oleh Panwaslu apakah sesuai dengan yang dimiliki oleh KPU jadi dalam hal ini Panwaslu memastikan bahwa pada penetapan tersebut tidak terjadi jumlah data yang berbeda antara yang di miliki oleh Panwaslu dan juga KPU . selain itu juga Panwaslu melalukan pengawasan terhadap KPU dengan menghadiri langsung setiap sosialisasi yang dilakukan oleh KPU seperti yang tercantum didalam Undang-udang bahwa Panwaslu menggawasi pelaksanaan sosialisasi

\section{Pengawasan Terhadap Pemilih}

Panwaslu juga melakukan pengawasan terhadap pemilih yaitu Aparatur Sipil Negara atau (ASN) serta masyrakat umum. Panwaslu melakukan pengawasan terhadap ASN dengan cara memantau serta dengan menerima laporan pengaduan jika terjadi pelanggaran yang dilakukan oleh ASN contoh pelanggaran yang terjadi di kota Tangerang yaitu ASN melakukan kampanye dengan menggunakan atribut partai dan juga tidak memberikan surat pemberitahuan terlebih dahulu terhadap Panwaslu.

Hal ini terjadi di kecamatan Batuceper, Kota Tangerang bahwa terdapat Oknum ASN yang melakukan kampanye dengan menggunakan Atribut partai salah satu calon dan juga tidak memberikan surat pemberitahuan kepada Panwaslu. seperti yang disampaikan oleh Ketua Panwaslu Kecamatan BatuCeper:

"Untuk ASN memang sulit untuk ditertibkan agar tidak melakukan pelanggaran, namun kami sering mendapat laporan dari Panwas kelurahan bahwa ada ASN melakukan kampanye dangan menggunakan atribut partai tertentu dan juga tidak memberikan surat pemberitahuan dulu kepada kami baik lisan atau surat" (AlhujajKetua Panwascam Batuceper) 
Panwaslu juga dalam temuan-temuan pelanggaran masih mengandalkan kepada laporan yang masuk, seharusnya panwaslu melakukan pemantauan secara langsung di lapangan dan tidak hanya bertindak jika adanya laporan saja . karena fakta dilapangan panwaslu tidak akan melakukan penindakan jika tidak adanya laporan yang masuk kepada Panwaslu, terlebih pada tingkat kecamatan yang tidak terlalu responsive dalam menyikapi setiap indikasi yang ada. hal ini juga seharusnya menjadi sorotan dari Panwaslu Kota sesuai dengan Udang-undang bawasannya Panwaslu tingkat kota harus melakukan pembinaan kepada tingkatan dibawahnya.

Sesuai dengan prinsip penyelenggaraan pemilihan yang demokratis Panwaslu Kota Tangerang Sebagai Penyelenggara Pemilu sudah memenuhi beberapa prinsi penyelenggaraan yaitu Free Election dimana Panwaslu Kota Tangerang memberikan kebebasan masyarakat dan peserta pemilu untuk dapat memilih dan dipilih serta dapat ikut melakukan atau turut serta dalam memantau dan mengawasi proses tahapan pemilu hal ini dapat dilihat dari dibukanya posko pengaduan jika terjadi tindak pelanggaran namun memang belum semua masyarakat memahami tatacara pelaporan yang harus mereka lakukan jika masyarakat melihat indikasi pelanggaran, Panwaslu sudah seharusnya memberikan edukasi dan tatacara pelaporan yang mudah dipahami oleh masyarakat luas agar dapat terciptanya pemilu yang demokratis dengan melibatkan masyarakat.

Selanjutnya prinsip Fair Election, dimana penyelenggara sudah seharusnya menjunjung kesetaraan (Hikmawan, 2017a) dalam artian tidak menguntungkan salah satu pihak yang berkompetisi. Pada penyelenggaraan Pilgub Banten 2017 Panwaslu sudah dapat menjunjung kesetaraan kepada pihak yang berkompetisi hal tersebut dapat dilihat dari diterimanya segala laporan pengaduan yang masuk dari kedua timsukses calon namun memang tidak semua diproses oleh Panwaslu dengan alasan bahwa fakta atau data temuan dilapangan belum dapat memenuhi unsur untuk dapat diproses lebih lanjut.

Selanjutnya prinsip universal suffrage, prinsip yang sudah seharusnya dimiliki penyelenggara pemilu yaitu menjamin hak para pemilih untuk dapat memilih terpenuhi. Panwaslu Kota Tangerang melakukan perannya sebagai pengawas agar menjamin semua warga Kota Tangerang untuk dapat memilih dapat terpenuhi dengan cara menyandingkan data pemilih melalui DP4 dan menyandingkan data dengan KPU untuk memastikan hak masyarakat untuk dapat memilih terpenuhi.

Equal Suffrage, yaitu setiap warga negara memiliki satu suara dan setiap suara ditakar dengan nilai yang sama, sebagai penyelenggara Panwaslu Kota Tangerang sudah seharusnya memastikan bahwa para peserta pemilih untuk dapat memilih dan juga memiliki satu suara dan ditakar dengan nilai yang sama dengan pemilih lainnya. Panwaslu Kota Tangerang melakukan pengawasan di berbagai tempat pemungutan suara atau TPS melalui Pengawas Pemilu Lapangan (PPL) pada setiap kelurahan dan juga Pengawas Tempat Pemungutan Suara (PTPS) untuk dapat memastikan bahwa semua warga dapat atau tidak dapat memilih pada saat pemungutan suara serta memastikan semua mendapatkan haknya dengan baik. Voting by Secret Ballot, prinsip pemilu yang demokratis yatu penyelenggara dapat memastikan kerahasiaan pilihan dari para pemilih. Panwaslu 
Kota Tangerang memastikan kerahasiaan para pemilih dengan cara memastikan setiap TPS tidak terdapat paksaan dari pihak manapun dengan hadirnya pengawas disetiap TPS, lalu yang terakhir yaitu Honest Counting and Reporting of Result, memastikan pada setiap pemungutan serta hasil pemungutan suara para penyelenggara dan pihak terkait bertindak secara profesional, efisien dan akurat. Panwaslu Kota Tangerang memastikan bahwa hasil pemungutan suara di TPS berjalan dengan terbuka dan disaksikan sesuai dengan prosedur namun dalam beberapa kasus seperti di wilayah Karawaci terdapat pembukaan kotak suara tidak sesuai prosedur dan akhirnya dilakukan Pemungutan Suara Ulang (PSU) diwilayah tersebut karena hal tersebut Panwaslu melakukan rekomendasi kepada KPU dengan memberikan bukti dilapangan melalui laporan PTPS dan PPL dilapangan untuk melakukan pemungutan suara ulang di wilayah tersebut.

\section{Tindak Lanjut Pelanggaran Pilgub Banten 2017 di Kota Tangerang}

Panitia Pengawas Pemilihan Umum (Panwaslu) Kota Tangerang bersama Dinas Kebersihan dan Pertamanan (DKP) Kota Tangerang melakukan penertiban Alat Peraga Kampanye (APK) yang terpasang di wilayah Kota Tangerang. Meski diikuti dua Pasang Calon (Paslon) Gubernur dan Wakil Gubernur Banten, spanduk dan baliho paslon sudah tersebar disetiap wilayah jauh hari sebelum ditetapkan sebagai peserta Pilgub. Akibatnya, baliho ataupun spanduk dan APK lainnya, menggangu pemandangan di wilayah Kota Tangerang.

"Penertiban ini dilakukan sesuai dengan instruksi Badan Pengawas Pemilihan Umum (Bawaslu) Provinsi Banten untuk menertibkan APK Paslon sebelum kampanye. Karena, belum diatur pemasangan APK. KPU Provinsi Banten sudah menetapkan tahap kampanye di mulai 28 Oktober 2016," (Kata Ketua Panwaslu Kota Tangerang, Agus Muslim).

Panwaslu Kota Tangerang terus menertibkan APK di seluruh wilayah Kota Tangerang. Bagi Paslon dan Tim Suksesnya yang masih memasang APK yang tidak sesuai dengan peraturan KPU. Dikatakannya, semua ditindak dengan tegas kepada paslon tersebut.

"Kami memberikan sanksi yang tegas kalau masih bandel memasang APK dengan memberhentikan kampanye".(M Agus Muslim - Ketua Panwaslu Kota Tangerang)

Namun dilapangan Panwaslu Kota Tangerang tidak memberikan sanksi yang tergas terhadap APK yang masih terpasang yang tidak sesuai dengan peraturan KPU, Panwaslu hanya memberikan surat teguran dan rekomendasi kepada Partai untuk dapat menertibkan APK yang tidak sesuai dengan peraturan KPU .

Jajaran Kepolisian Resort (Polres) Metro Tangerang Kota, Komisi Pemilihan Umum (KPU) Kota Tangerang dan Pengawas Pemilihan Umum (KPU) Kota Tangerang komitmen menjadikan Pemilihan Gubernur dan Wakil Gubernur Banten 2017 Bersih dan Obyektif. Demikian hal itu terungkap saat Pemaparan Pilkada Bersih dan Obyektif kepada seluruh jajaran Bhabikamtibmas (Bhayangkara Pembina Keamanan dan Ketertiban Masyarakat) se-Kota Tangerang, di Aula Polres Metro Tangerang Kota, oleh Kapolres Metro Tangerang, Kombespol Irman Sugema, Ketua KPU Kota Tangerang, Sanusi, dan Ketua Panwaslu Kota Tangerang Agus Muslim, Jumat 30 Januari 2016.

Dari hasil penelitian ini didapati beberapa pelanggaran yang ditemui oleh 
Panwaslu Kota Tangerang, bahka pada saat itu Panwaslu Kota Tangerang merekomendasikan ada empat TPS dari dua Kecamatan di Kota Tangerang melaksanakan Pemungutan Suara Ulang (PSU), karena adanya temuan pelanggaran. Empat TPS yang harus melakukan PSU pada saat itu adalah TPS 7 (Kelurahan Kelapa Indah) dengan total jumlah pemilih 403 yang terdiri dari Calon Nomor Urutan 1 memperoleh suara 302 sementara Calon Nomor urutan 2 memperoleh suara 100 dan 1 suara dinyatakan tidak sah, TPS 3 (Kelurahan Sukarasa) dengan total jumlah pemilih 188 yang terdiri dari Calon Nomor Urutan 1 memperoleh suara 34 sementara Calon Nomor Urutan 2 memperoleh suara 153 dan 1 suara dinyatakan tidak sah dimana kedua TPS berada di wilayah Kecamatan Tangerang. Sedangkan dua TPS lagi yang melakukan PSU yaitu TPS 5 dengan total jumlah pemilih 356 yang terdiri dari Calon Nomor Urutan 1 memperoleh suara 240 sementara Calon Nomor Urutan 2 memperoleh suara 110 dan 6 suara dinyatakan tidak sah dan TPS 15 dengan total jumlah pemilih 345 yang terdiri dari Calon Nomor Urutan 1 memperoleh suara 205 sementara Calon Nomor Urutan 2 memperoleh suara 128 dan 12 suara dinyatakan tidak sah dimana kedua TPS tersebut dalam satu Kelurahan Nusajaya Kecamatan Karawaci, dan pada saat PSU dilaksanakan dihadiri oleh Tim Pengkaji dan Panwascam.

Dari beberapa wawancara diatas didapatkan informasi bahwa dalam menjalankan tugasnya Panwaslu Kota dibantu oleh Panwascam dan juga PPL, informasi pelanggaran yang terjadi diwilayah disampaikan oleh seluruh jajaran kecamatan kepada tingkat Kota. Mulai dari titik rawan yang ada diwilayah Kecamatan, Pengawasan terhadap PPK hingga laporan masyarakat yang masuk diwilayah Kecamatan. Tatacara pelaporan yang belum tersosialisasi pun disampaikan oleh Komisioner Panwaslu Kota Tangerang :

"Untuk masyarakat dapat melaporkanya langsung kekantor kami namun yang menjadi kendala juga banyak yang belum tau dan kurang dalam tata cara pelaporan ini, dan mereka kira apabila melapor pasti kita proses namun sebenarnya mekanismenya tidak seperti itu, kami terima namun dikaji kembali apakah memenuhi unsur pelanggaran atau tidak." (Hery Handani - Komisioner Panwaslu Kota Tangerang)

Selain dengan Komisioner Panwaslu Kota Tangerang, KPU dan Panwascam peneliti mendapat informasi dari salah satu masyarakat atau warga peserta pilgub dalam penyelenggaraan pilgub ini. Menurut pandangan Khairul Imam warga Kecamatan Batuceper dalam pelaksanaan pilgub ini:

"Di wilayah saya panwas tidak bergerak dengan cepat, karena saya sebagai saksi dan melaporkan kejadian di wilayah batuceper bahwa ada pelanggaran dan tidak terlalu di tanggapi dengan serius, saya pada waktu itu melaporkan ketua PPK batuceper karena berpihak kepada salah satu calon ketua PPK tersebut melalui whatsapp menuliskan dirinya mengaku orang $R K$. pada saat itu saya dipanggil jadi saksi dengan beberapa orang tapi pada akhirnya tidak ada yang dilakukan oleh panwas kota dan akhirnya ya tidak ada yang di proses. (Khairul Imam / Warga peserta Pilgub 2017).

Tata cara pengaduan pelanggaran masih banyak belum diketahui warga sehingga juga partisipasi masyarakatpun kurang dalam melakukan pelaporan pelanggaran seperti yang dikatakan ketua Panwascam Batuceper 
"Untuk tata cara kami membuat posko pengaduan, seperti pengaduan jika nama anda tidak ada di DPT maka bisa melaporkan ke kami, jika melihat pelanggaran bisa langsung laporkan, jadi kami terbuka saja. sedangkan partisipasi masyarakat masih kurang, ya mungkin memang sebagian masyarakat masih belum tahu apa itu panwascam, namun kalau di sebut KPU baru paham. Ya mungkin memang masih kurang pemahaman dan sosialisai yang diberikan sehingga tidak mengerti pentingnya partisipasi masyarakat dalam pengawasan." (Alhujaj - Ketua Panwascam Batuceper)

Berdasarkan hasil penelitian dan temuan-temuan lapangan, maka kesimpulan akhir yang didapat peneliti mengenai peran pengawasan Panwaslu Kota Tangerang pada pilgub Banten 2017 terlihat bahwa Panwaslu mempunyai peranan yang penting dalam rangka mengawal pelaksanaan pemilu sesuai dengan peraturan perundang- undangan yang berlaku. Panwaslu Kota Tangerang memiliki peran dalam mengawasi KPU sebagai penyelenggara Pemilu, Pasangan RanoEmbay dan Wahidin-Andika sebagai Peserta Pemilu dan juga Masyarakat serta Aparatur Sipil Negara didalamnya sebagai Pemilih. Dalam melakukan pengawasan terhadap penyelenggara pemilu yaitu KPU Kota Tangerang, Panwaslu Kota Tangerang mengawasi Penyelenggara Pemilu yaitu dengan cara mengikuti setiap kegiatan atau tahapan yang dilakukan oleh KPU pada saat melakukan pengawasan tersebut Panwaslu memiliki lembar laporan yang nantinya akan menjadi acuan dalam melakukan segala tindakan jika terjadi pelanggaran yang terjadi yang dilakukan oleh KPU dan Panwaslu berhak memberikan rekomendasi .

Selain mengawasi penyelenggara pemilu Panwaslu juga mengawasi peserta pemilu dalam mengawasi peserta pemilu panwaslu mengawasi mulai dari peserta mencalonkan diri hingga pada tahapan kampanye dimana sering terjadi pelanggaran dan juga pada pemungutan suara panwaslu mengawasi langsung serta juga melalui jajaran dibawahnya serta menerima laporan pengaduan jika memang terjadi indikasi pelanggaran namun tidak semua yang laporan yang masuk akan langsung dapat di tindak lanjuti oleh Panwaslu, selain itu juga panwaslu mengawasi pemilih, dalam mengawasi pemilih itu sendiri seperti mengawasi daripada netralitas Aparatur Sipil Negara (ASN) Panwaslu juga mengingatkan serta memberikan peringatan terhadap ASN terlebih dengan memberikan sosialisasi tentang pentingnya netralitas ASN dalam pemilu, namun yang terjadi masih saja ditemukan pelanggaran yang dilakukan ASN dan Panwaslu hanya dapat memberikan surat peringatan atau melakukan pemanggilan namun tidak dilakukan sanksi apapun terhadap pelanggar tersebut. Panwaslu juga dibantu oleh jajaran dibawahnya yaitu Panwaslu tingkat Kecamatan atau Panwascam seta Pengawas tingkat kelurahan dan pengawas tingkat TPS.

Sesuai dengan prinsip penyelenggaraan pemilihan yang demokratis Panwaslu Kota Tangerang Sebagai Penyelenggara Pemilu sudah memenuhi beberapa prinsip penyelenggaraan yaitu Free Election dimana Panwaslu Kota Tangerang memberikan kebebasan masyarakat dan peserta pemilu untuk dapat memilih dan dipilih serta dapat ikut melakukan atau turut serta dalam memantau dan mengawasi proses tahapan pemilu hal ini dapat dilihat dari dibukanya posko pengaduan jika terjadi tindak pelanggaran namun memang belum semua masyarakat memahami tatacara pelaporan. Selanjutnya prinsip Fair Election pada penyelenggaraan Pilgub Banten 
2017 Panwaslu sudah dapat menjunjung kesetaraan kepada pihak yang berkompetisi hal tersebut dapat dilihat dari diterimanya segala laporan pengaduan yang masuk dari kedua timsukses calon namun memang tidak semua diproses oleh Panwaslu. Prinsip universal suffrage Panwaslu Kota Tangerang melakukan perannya sebagai pengawas agar menjamin semua warga Kota Tangerang untuk dapat memilih dapat terpenuhi dengan cara menyandingkan data pemilih melalui DP4 dan menyandingkan data dengan KPU untuk memastikan hak masyarakat untuk dapat memilih terpenuhi.

Selanjutnya Equal Suffrage Panwaslu Kota Tangerang untuk dapat memastikan bahwa semua warga dapat atau tidak dapat memilih pada saat pemungutan suara serta memastikan semua mendapatkan haknya dengan baik yaitu dengan melakukan pengawasan di berbagai tempat pemungutan suara atau TPS melalui Pengawas Pemilu Lapangan (PPL) pada setiap kelurahan dan juga Pengawas Tempat Pemungutan Suara (PTPS) . lalu Counting and Reporting of Result Panwaslu Kota Tangerang memastikan bahwa hasil pemungutan suara di TPS berjalan dengan terbuka dan disaksikan sesuai dengan prosedur namun dalam beberapa kasus seperti di wilayah Karawaci terdapat pembukaan kotak suara tidak sesuai prosedur dan akhirnya dilakukan Pemungutan Suara Ulang (PSU) diwilayah tersebut karena hal tersebut Panwaslu melakukan rekomendasi kepada KPU dengan memberikan bukti dilapangan melalui laporan PTPS dan PPL dilapangan untuk melakukan pemungutan suara ulang di wilayah tersebut. Hal tersebut dilakukan untuk mencapai pemilihan Gubernur dan Wakil Gubernur yang Langsung, Umum, Bebas, Rahasia, Jujur dan Adil (Luber Jurdil).

Panwaslu di Tingkat Provinsi, Kabupaten/Kota, dan Kecamatan merupakan panitia pengawas yang masih bersifat ad-hoc, sehingga keberadaannya masih bersifat kurang stabil. PPL dan PTPS adalah Panitia pengawas ujung tombak yang keberadaannya sangat dibutuhkan dalam peran pengawasan ditingkat paling bawah. Dengan demikian sudah selayaknya dalam melaksanakan tahapan-tahapan seperti pembentukan PPL dan PTPS harus memperhatikan hal-hal sosialisasi tentang kepemiluan terhadap wilayah-wilayah yang masih kurang dalam pemahaman pemilu khususnya dalam bidang pengawasan pemilu sehingga animo masyarakat untuk ikut berpartisipasi menjadi pengawas akan lebih baik.

Berbagai kendala yang dihadapi Tim Panwaslu dalam proses penyelenggaraan Pilgub dan Wagub Banten 2017 ternyata dapat dipecahkan dan menjadi pengalaman berharga bagi Tim Panitia Pengawas Pemilihan Umum Kota Tangerang dalam malaksanakan tugas-tugas lain dan atas permasalahan yang dijumpai dapat menjadi acuan dan menjadi pengalaman dalam hal penyelesaian masalah dimasa yang akan datang, karena Panitia Pengawas Pemilihan Umum Kota Tangerang menyadari bahwa apa yang telah dilakukan jauh dari harapan sempurna sehingga masih harus terus memperbaiki dan mendalami untuk menghadapi permasalahan yang timbul saat menjalankan tugas kepengawasan di masa yang akan datang. Untuk memaksimalkan perannya dalam pengawasan Pilgub dan Wagub, sudah seharusnya melakukan beberapa cara di antaranya sosialisasi yang dilakukan panwaslu untuk memberi pengetahuan kepada masyarakat tentang pilkada dan kemungkinan pelanggaran- pelanggaran yang terjadi; pengawasan aktif, untuk mencegah terjadinya pelanggaran pilkada, dan melaporkannya bila terjadi; memaksimalkan pengawasan masyarakat dengan 
melibatkan tokoh-tokohnya untuk membantu melakukan pengawasan terhadap pelanggaran yang mungkin terjadi di sekitar wilayah Kota Tangerang.

\section{Kesimpulan}

Pada akhirnya semua tahapan dalam pelaksanaan Pemilihan Gubernur Dan Wakil Gubernur Banten Tahun 2017 di Kota Tangerang dapat terlaksana dengan baik dan dapat menghasilkan kinerja yang mudah-mudahan dapat dievaluasi dengan obyektif sehingga di periode berikutnya semua panwas dijajaran masingmasing mampu mengemban tugas pengawasan diwilayah kerja masing-masing dengan sebaik-baiknya. Pengalaman pada pencoblosan pemilu lalu yang banyak terdapat kejanggalan- kejanggalan dalam penghitungan suara harus menjadi pelajaran bagi kita dan diantisipasi. Kedua, membuat sebuah petunjuk yang sistematis dan praktis agar Panwaslu di tingkat bawah bisa bertindak secara cepat apabila menemui pelanggaran- pelanggaran pada pelaksanaan Pilkada. Ketiga, mempertegas aturan dan sanksi mengenai pelanggaran terhadap penggalangan massa, pawai dan membayar massa. Keempat, mempertegas aturan yang melarang penggunaan fasilitas pemerintah/negara untuk keperluan kampanye. Yang terakhir dan saat ini marak terjadi adalah mengawasi agar isi kampanye tidak menfitnah atau melakukan kampanye negatif. Ternyata membuka aib orang dan mejelekkan kandidat lain tanpa disertai dengan argumen dan bukti yang kuat sudah menjadi kebiasaan dalam setiap suksesi politik, hal ini harus dihindari dalam upaya membangun upaya politik santun dan demokrasi di tingkat lokal. Dengan demikian, diharapkan dalam penyelenggaraan pemilihan dikemudian hari dapat berjalan pemilihan yang lebih baik dari berbagai aspek penyelenggaraan terlebih terhadap pengawasan dalam pemilihan umum yang terselenggara di Kota Tangerang.

\section{References}

Abdullah, Rozali, (2007). Pelaksanaan Otonomi Luas Dengan Pemilihan Kepala Daerah Secara Langsung, RajaGrafindo Persada, Jakarta

Abu, Ahmadi, (1982). Psikologi Sosial, Surabaya: PT. Bina Ilmu.

Bungin, Burhan, (2004). Metode Penelitian Kualitatif, Jakarta, Bumi Aksara.

Creswell John.W. (2014). Penelitian Kualitatif \& Desain Riset. Yogyakarta: Pustaka Pelajar.

Dani, Karim. (2006). Sistem Politik dan Pemilu di Indonesia. Ghalia Indonesia. Jakarta

Danial, endah dan Nanan wasriah. (2009). Metode Penulisan Karya Ilmiah. Bandung: 
Volume 1 Issue 1, April 2019

http://hk-publishing.id/ijd-demos

Laboratorium Pendidikan Kewarganegaraan.

Good-Gill, (1995). Pemilu Jurdil: Pengalaman dan Standar Internasional.

Jakarta: PIRAC\&The Asia Fpundation.

Handoko, T. Hani. (1996). Manajemen Personalia dan Sumber Daya Manusia.

Yogyakarta : BPFE. Wasistiono Sadu, Yonatan Wiyoso, 2009, Meningkatkan

Kinerja Dewan Perwakilan Rakyat, Bandung, Fokus Media

Haryadi, Achmad Dodi. (2012). Demokrasi lokal : Evaluasi Pemilukada Di Indonesia,

Jakarta: Konstitusi Press.

Hikmawan, M. D. (2014). Politik Perbedaan : Demokrasi dalam Paradoks. Universitas Gdjah Mada.

Hikmawan, M. D. (2017a). Pluralisme Demokrasi Politik di Indonesia. Journal of Governance, 2(2), 223-247.

https://doi.org/http://dx.doi.org/10.31506/jog.v2i2.2678

Hikmawan, M. D. (2017b). Politik Perbedaan: Minnoritas dalam Implementasi

Kebijakan. Journal of Indonesian Public Administration and Governance Studies (JIPAGS), 1(1), 88-98.

Hikmawan, M. D., \& Hidayat, R. (2016). Depoliticisation of Public Issue : Low

Degree of Government ' S Democratic Legitimacy. Journal of Governance, 1(1),

23-37. https:// doi.org/http://dx.doi.org/10.31506/jog.v1i1.1311

Horoepoetri, Arimbi, Achmad Santosa, (2003). Peran Serta Masyarakat Dalam Pengelolaan Lingkungan, Jakarta: Walhi.

Huntington, Samuel P, (2001). Benturan antar Peradaban, Yogyakarta: Qalam.

Moleong, Lexy J. (2007) Metodologi Penelitian Kualitatif, Penerbit PT Remaja Rosdakarya Offset, Bandung

Nasution,S. (1996) . Metode Penelitian Naturalistik Kualitatif. Bandung. Tarsito

Nasution,S. (2003) . Metode Penelitian Naturalistik Kualitatif. Bandung. Tarsito

Prihatmoko, (2003), Pemilihan Kepala daerah Langsung, Penerbit

Pustaka Pelajar, Yogyakarta.

Rizkiyansyah, F.K. (2007). Mengenal Pemilu Menatap Demokrasi. Bandung: IDEA Publishing.

Sarwono, S.W. (2002). Psikologi Sosial. Jakarta: Balai Pustaka

Siagian, Sondang P. (1990).Organisasi Kepemimpinan dan Perilaku

Organisasi.Jakarta:Gunung Agung.

Soeharyo Salamoen dan Effendy Nasri. (2006). Sistem Penyelenggaraan Pemerintah

Negara Kesatuan Rebublik Indonesia. Lembaga Administrasi Negara. Jakarta

Soekanto, Soerjono, (2002). Teori Peranan, Jakarta, Bumi Aksara.

Sugiyono. (2012). Metode Penelitian Kuantitatif Kualitatif dan R\&D. Bandung: Alfabeta. Terry, G.R dan L.W Rue. (1999). Principles of Management, Diterjemahkan oleh G. A

Surbakti, Ramlan (1992). Memahami Ilmu Politik. Jakarta: PT Gramedia Widiasarana 
Volume 1 Issue 1, April 2019

http:/ /hk-publishing.id/ijd-demos

Indonesia

Surbakti, Ramlan dan Kris Nugroho. (2015). Studi Tentang Desain Kelembagaan Pemilu yang Efektif. Kemitraan bagi Pembaruan Tata Pemerintahan : Jakarta

Surbakti, R. dan H. Fitrianto. (2015). Transformasi Bawaslu dan Partisipas Masyarakat dalam Pengawasan Pemilu. Kemitraan bagi Pembaruan Tata Pemerintahan : Jakarta

Ticoalu, (2007) Dasar-Dasar Manajemen. Cet VI. Jakarta: Bumi Aksara

Thoha, Miftah. (1997). Dimensi-dimensi Prima Ilmu Administrasi Negara. Jakarta: PT. Grafindo Pustaka Persada

Widiyanto, A., Hikmawan, M. D., \& Riswanda, riswanda. (2019). JSPG: Journal of Social Politics and Governance Implementasi Rencana Aksi Nasional Bela Negara Berdasarkan Instruksi Presiden Nomor 7 Tahun 2018 Oleh Dewan Ketahanan Nasional Republik Indonesia. Journal of Social Politics and Governance, 1(2), 95-115. 